\title{
Tracheobronchial injuries in chest trauma: a 17-year experience
}

\section{Lesões traqueobrônquicas no trauma torácico: experiência de 17 anos}

\author{
Roberto SaAd JR, TCBC-SP1; Roberto Gonçalves, TCBC-SP1; Vicente Dorgan Neto, TCBC-SP1; Jacqueline Arantes G. Perlingeiro,
} TCBC-SP1; Jorge Henrique Rivaben, ACBC-SP1; Márcio Botter, TCBC-SP'; José César Assef, TCBC-SP¹.

\begin{abstract}
A B S T R A C T
Objective: to discuss the clinical and therapeutic aspects of tracheobronchial lesions in victims of thoracic trauma. Methods: we analyzed the medical records of patients with tracheobronchial lesions treated at the São Paulo Holy Home from April 1991 to June 2008 . We established patients' severity through physiological (RTS) and anatomical trauma indices (ISS, PTTI). We used TRISS (Trauma Revised Injury Severity Score) to evaluate the probability of survival. Results: nine patients had tracheobronchial lesions, all males, aged between 17 and 38 years. The mean values of the trauma indices were: RTS - 6.8; ISS - 38; PTII - 20.0; and TRISS - 0.78. Regarding the clinical picture, six patients displayed only emphysema of the thoracic wall or the mediastinum and three presented with hemodynamic or respiratory instability. The time interval from patient admission to diagnosis ranged from one hour to three days. Cervicotomy was performed in two patients and thoracotomy, in seven (77.7\%), being bilateral in one case. Length of hospitalization ranged from nine to 60 days, mean of 21. Complications appeared in four patients (44\%) and mortality was nil. Conclusion: tracheobronchial tree trauma is rare, it can evolve with few symptoms, which makes immediate diagnosis difficult, and presents a high rate of complications, although with low mortality.
\end{abstract}

Keywords: Bronchi. Thoracic Injuries. Thoracic Surgery. Trachea.

\section{INTRODUCTION}

$\mathrm{T}$ racheobronchial lesions resulting from both closed and penetrating thoracic trauma are rare and often fatal. The bronchial treehas great elasticity and mobility. It is naturally protected by the shoulder girdle, in all its extension in the cervico-thoracic transition, anteriorly by the mandible and sternum, posteriorly by the spinal column and laterally by the bones and muscles of the costal grid. Hence, it is rarely affected by thoracic trauma. In general, the incidence of tracheobronchial lesions ranges from 0.3 to $1 \%$. In large urban trauma centers, with 2,500 to 3,000 admissions per year, two to four tracheobronchial lesions occurannually. In 1,178 necropsies after trauma, 33 (2.8\%) patients with tracheobronchial lesions were found, of which 27 (81.8\%) died almost immediately after trauma'.

The larynx and cervical trachea are most often subject to open lesions, whereas the thoracic trachea and bronchi are sites of lesions caused by closed trauma.

In the last decades, with the improvement of prehospital care and transportation, the number of patients with this type of trauma who arrive alive in the emergency room has increased ${ }^{2-5}$. Success in the diagnosis and treatment of such lesions requires a high level of suspicion, particularly in closed trauma, in which they may go unnoticed due to the occurrence of associated lesions. Some authors report rates of 25 to $68 \%$ of immediately undiagnosed tracheobronchial lesions ${ }^{3,6}$.

The clinical picture may be poor, which hampers diagnosis and, consequently, postpones treatment, compromising the restoration of pulmonary function and determining the appearance of complications and death.

In this study, after 17 years of experience, we aimed to analyze the difficulty of diagnosis, the most appropriate treatment, complications and mortality.

\section{METHODS}

We conducted a review of the trauma protocols and medical records of all patients who were victims of closed or penetrating chest trauma treated at the Emergency Department of the Department of Surgery of the Faculty of Medical Sciences of the São Paulo Holy Home, between 1991 and 2008. This study

1 - Faculty of Medical Sciences of the São Paulo Holy Home, Department of Surgery, São Paulo, São Paulo State, Brazil. 
was approved by the Ethics and Research Committee of the Faculty of Medical Sciences the São Paulo Holy Home (protocol \# 052/11).

We included all patients with tracheobronchial lesions above the age of 14. Younger individuals were treated at the Pediatric Service. We excluded cases with iatrogenic lesions (intubation, surgical manipulation), those exposed to the ingestion of chemical agents or those who sustained injuries caused by hot vapors.

We characterized patient severity by the physiological (RTS - Revised Trauma Score) and anatomical (ISS - Injury Severity Score, and PTTI Penetrating Thoracic Trauma Index). We used the TRISS - Trauma Revised Injury Severity Score - to evaluate the probability of survival. It consists of the combination of physiological (RTS) and anatomical (ISS) parameters with the patient's age and the mechanism of trauma.

The RTS, created by Champion et al. ${ }^{7}$, in 1989, ranges from 0 to 7.84, and the highest values are associated with a better prognosis. This index is based on the Glasgow coma scale, systolic blood pressure and respiratory rate at admission.

The ISS and the PTTI aim at evaluating the organs affected and quantifying the associated complications. The ISS, proposed by Baker et al. ${ }^{8}$, varies from 1 to 75: the higher this index, the greater the trauma severity. It relies on the degree of injury of each organ for each body segment.

The analyzed variables included age, gender, etiologic agent, trauma mechanism, hemodynamic status at admission, diagnosis, treatment, complications and mortality. Although the number of cases was small, we mainly sought to quantify the time that was necessary to make the diagnosis between the arrival of the victim and the finding of the tracheobronchial lesion.

\section{RESULTS}

Nine patients had tracheobronchial lesions, which meant an average of 0.5 patients per year. All were male, aged between 17 and 38 years, mean of 26. The lesions were produced by penetrating wounds in six cases (66.6\%), four of them by firearm projectiles and two by stabbing. The remaining three patients were victims of closed traumas, all run over.

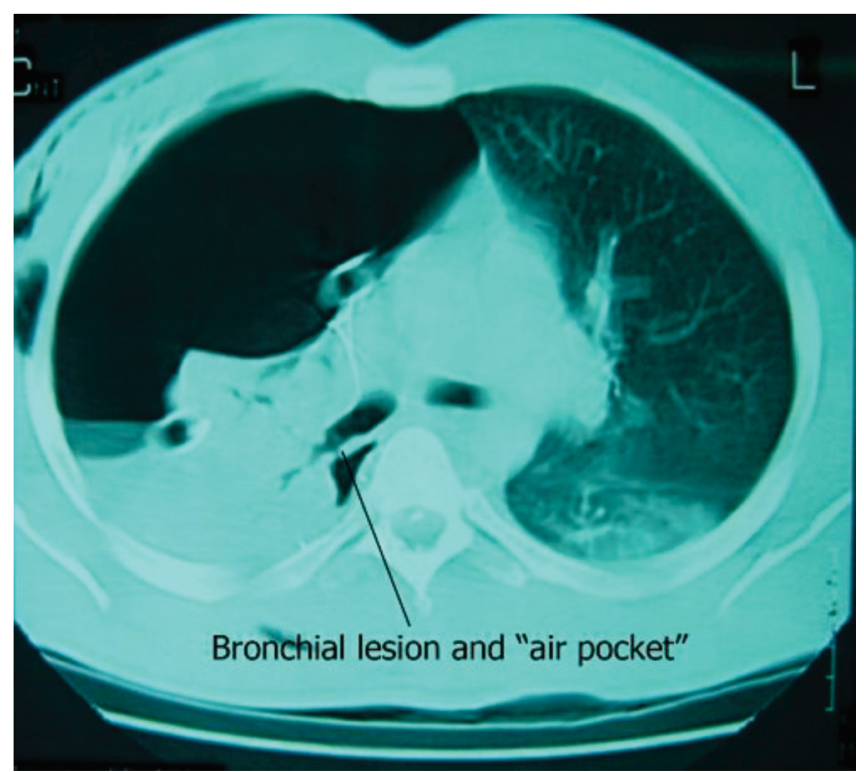

Figure 1. Bronchial lesion diagnosed by computed tomography. Notice continuity solution in the right stem bronchus and accumulation of air, just below the lesion.

Regarding the clinical picture, six patients presented only emphysema of the thoracic wall or the mediastinum and they arrived hemodynamically stable in the Emergency Room. At admission, three presented with hemodynamic or respiratory instability, one with hypertensive pneumothorax, one with open pneumothorax and one with massive hemothorax.

The trauma indices averages observed in the nine individuals with tracheobronchial lesions are shown in Table 1.

The time interval required from patient admission to diagnosis ranged from one hour to three days, the majority within 24 hours (Table 2).

Bronchoscopy was performed in six cases and detected the lesions in four of them: one patient with a left tracheal lesion $4 \mathrm{~cm}$ from the vocal folds, one with a tracheal lesion $2 \mathrm{~cm}$ from the carina, one with a left bronchial lesion, and one with a bilateral stem bronchial lesion, but diagnosed only of the left lesion,

Table 1. Average values of trauma indexes.

\begin{tabular}{cc}
\hline Index & Average values \\
\hline RTS & 6.8 \\
ISS & 38 \\
PTTI & 20 \\
TRISS & 0.78 \\
\hline
\end{tabular}




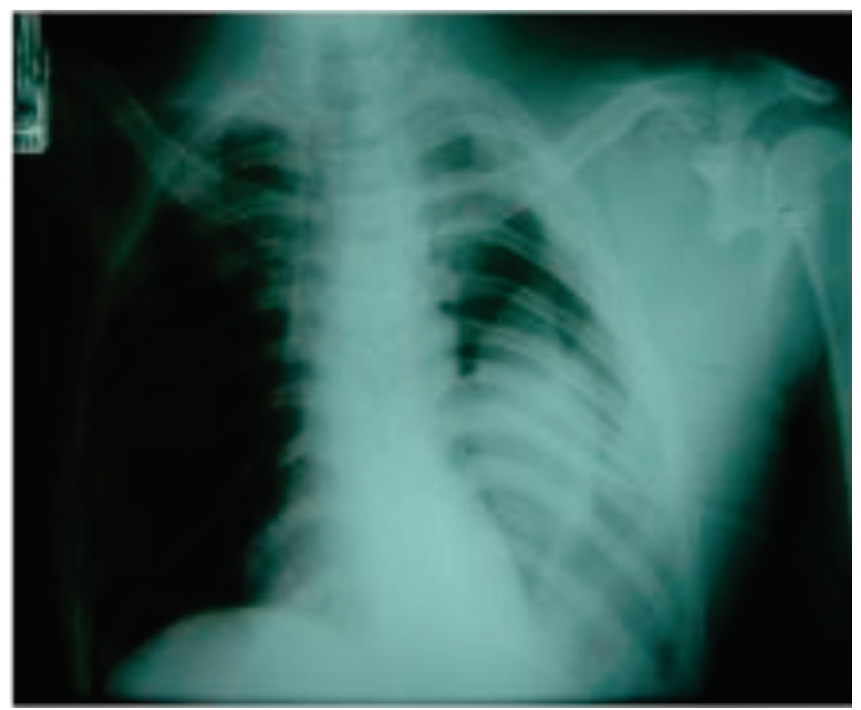

Figure 2. Chest radiograph. "Fallen lung" sign and complex scapular fracture to the left, denoting a high-energy trauma.

$1.5 \mathrm{~cm}$ from the carina, the lesion on the right going unnoticed. In the others, the diagnosis was imminently clinical-radiological.

As for evolution and treatment, the patients were submitted to pleural drainage on admission. The bubbling in the drainage system suggestive of a large bronchopleural fistula was observed in six (66.6\%) patients.

All patients underwent surgery, and the time elapsed between admission and the operative procedure ranged from one hour to thirty days, most in 30 hours, due to the difficulty in diagnosis.

In both cases of cervical tracheal lesions, the diagnosis was immediate, and primary suture of the lesions was performed, without tracheostomy. One of them, a victim of gunshot injury, had an associated esophageal lesion that was debrided and sutured, with a muscular flap interposition between the esophagus and the trachea.

Posterolateral thoracotomy was performed in seven $(77.7 \%)$ patients, three on the left, three on the right and one bilateral.

Regarding the type of lesion found in the intraoperative period, we observed a partial airway section in seven (70\%) cases and a complete section in three $(30 \%)$. It is worth remembering that there were nine patients, but with a total of ten main respiratory tree injuries.

One of the patients, a victim of infraclavicular gunshot wound with an intrathoracic tracheal lesion
$2 \mathrm{~cm}$ from the carina in its membranous portion, also had an esophageal lesion $25 \mathrm{~cm}$ from the upper dental arch and a thoracic duct lesion. Access was through a right thoracotomy, withdebridement and suture of the trachea and esophagus wounds, and ligation of the thoracic duct. The esophageal lesion was tangential. This patient evolved with pleural empyema, but with good resolution and hospital discharge in nine days.

One patient had three gunshot wounds, one in the face, one left paravertebral and one abdominal. At admission, he had abdominal pain, oral bleeding, subcutaneous emphysema and pneumothorax. He was initially submitted to thoracic drainage, exploratory laparotomy and suture of the lip wound. Intraoperative pan-endoscopy was normal. He evolved well, but with persistent image of pulmonary collapse at chest radiograph and small air leak through the chest drain. The bronchoscopy was repeated and there was no evidence of airway lesion. Computed tomography of the chest was performed, showing an image suggestive of injury to the bronchus in the upper right lobe (Figure 1). He was submitted to right thoracotomy, which revealed an almost complete lesion, with ischemia of the remaining tissue in the emergence of the upper lobebronchus, and it was decided to complete the section of the bronchus, resecting all ischemic areas, with its subsequent reimplantation. There was no associated vascular lesion. There was immediate pulmonary re-expansion, but as a result of spinal cord injury and paraplegia, he evolved with pneumonia and the total hospitalization time reached 60 days.

The patient with stabbing wound on the back admitted in shock was drained and operated soon after admission. The exploratory laparotomy showed no lesion and he was then submitted to right thoracotomy due to hemodynamic instability and air leakage through the chest drain. The findings were a lesion in the bronchus to the inferior lobe and a concomitant arterial lesion, with active bleeding. Right inferior lobectomy was performed. He evolved with air fistula for seven days and partial atelectasis of the middle lobe that remained for ten postoperative days, but with satisfactory resolution with respiratory physiotherapy. 
Table 2. Characterization of patients with tracheobronchial injury.

\begin{tabular}{|c|c|c|c|c|c|c|c|c|c|}
\hline & Age & Trauma & Findings & $\begin{array}{l}\text { Associated } \\
\text { injuries }\end{array}$ & $\begin{array}{l}\text { Diagnostic } \\
\text { procedure }\end{array}$ & $\begin{array}{l}\text { Diagnosis } \\
\text { (time) }\end{array}$ & Surgery & $\begin{array}{l}\text { Length } \\
\text { of stay }\end{array}$ & Evolution \\
\hline 1 & 26 & Gunshot & Low trachea & $\begin{array}{l}\text { Esophageal } \\
\text { injury }\end{array}$ & Bronchoscopy & 1 hour & $\begin{array}{l}\text { Left } \\
\text { Thoracotomy }\end{array}$ & 9 days & $\begin{array}{l}\text { Empyema } \\
\text { Discharge }\end{array}$ \\
\hline 2 & 38 & Stabbing & $\begin{array}{l}\text { Cervical } \\
\text { trachea }\end{array}$ & No & Clinical and $x$-ray & $\begin{array}{l}\text { On } \\
\text { admission }\end{array}$ & Cervicotomy & 11 days & Discharge \\
\hline 3 & 28 & $\begin{array}{l}\text { Closed } \\
\text { trauma }\end{array}$ & $\begin{array}{l}\text { Left stem } \\
\text { bronchus }\end{array}$ & No & Bronchoscopy & 3 days & $\begin{array}{l}\text { Left } \\
\text { Thoracotomy }\end{array}$ & 60 days & Discharge \\
\hline 4 & 32 & Gunshot & $\begin{array}{l}\text { Left and right } \\
\text { Stem bronchus }\end{array}$ & No & Bronchoscopy & 1 day & $\begin{array}{l}\text { Bilateral } \\
\text { Thoracotomy }\end{array}$ & 10 days & Discharge \\
\hline 5 & 17 & Gunshot & $\begin{array}{l}\text { Cervical } \\
\text { trachea }\end{array}$ & $\begin{array}{l}\text { Esophageal } \\
\text { injury, chest } \\
\text { Gunshotwound } \\
\text { (hemothorax) }\end{array}$ & Bronchoscopy & 3 hours & Cervicotomy & 14 days & Discharge \\
\hline 6 & 19 & $\begin{array}{l}\text { Closed } \\
\text { trauma }\end{array}$ & $\begin{array}{l}\text { Left stem } \\
\text { bronchus }\end{array}$ & No & Clinical and x-ray & 8 hours & $\begin{array}{l}\text { Left } \\
\text { Thoracotomy }\end{array}$ & 40 days & $\begin{array}{l}\text { Empyema } \\
\text { Discharge }\end{array}$ \\
\hline 7 & 24 & Gunshot & $\begin{array}{l}\text { Right stem } \\
\text { bronchus }\end{array}$ & $\begin{array}{l}\text { Gunshotwounds } \\
\text { in face and } \\
\text { abdomen }\end{array}$ & Clinical and x-ray & 48 hours & $\begin{array}{l}\text { Right } \\
\text { Thoracotomy }\end{array}$ & 16 days & Discharge \\
\hline 8 & 20 & Stabbing & $\begin{array}{l}\text { Lower lobar } \\
\text { bronchus }\end{array}$ & No & Clinical and x-ray & 1 hour & $\begin{array}{l}\text { Right } \\
\text { Thoracotomy }\end{array}$ & 12 days & $\begin{array}{l}\text { Atelectasis of middle } \\
\text { lobe associated with } \\
\text { air leakage. } \\
\text { Discharge }\end{array}$ \\
\hline 9 & 34 & $\begin{array}{l}\text { Closed } \\
\text { trauma }\end{array}$ & $\begin{array}{l}\text { Left stem } \\
\text { bronchus }\end{array}$ & No & Clinical and x-ray & 72 hours & $\begin{array}{l}\text { Right } \\
\text { Thoracotomy }\end{array}$ & 18 days & Discharge \\
\hline
\end{tabular}

In the case of closed trauma with left bronchus lesion diagnosed three days after trauma, the radiograph at admission and during evolution showed persistent pneumothorax even after drainage and without air fistula. Chest tomography confirmed this image (sign of the "fallen lung"), also showing animportant pulmonary contusion, including extensive contralateral lung involvement (Figure 2). This patient was operated after clinical improvement of the pulmonary contusion, with 30 days of injury. The intraoperative finding was a partial lesion of the stem bronchus next to the carina, with exposure of the mucosa, requiring resection of the injured segment with end-to-end anastomosis.

In another patient with closed trauma, there was pneumothorax on the admission, which was drained. During arteriography to assess a possible subclavian lesion, he evolved with significant air leakage through the drain and, due to the unavailability of bronchoscopy, underwent bronchography showing a contrast "stop" image in the left stem bronchus. Left thoracotomy was performed, revealing a complete stem bronchus lesion, being treated with pneumonectomy. There was no associated vascular lesion. The time of mechanical ventilation was prolonged and tracheostomy was performed. He presented with pleural empyema and was discharged after 40 days of hospitalization.

The length of hospital stay in our series ranged from nine to 60 days, with a mean of 21 . Of the nine patients, three (33.3\%) evolved with complications, two pleural empyemas and one middle lobe atelectasis associated with air leakage. There were no deaths in this series.

Of theninepatients, five(55.5\%)hadassociated lesions. Table 2 brings the patients'characteristics. 


\section{DISCUSSION}

Tracheobronchial lesions are rare, occurring in $1 \%$ to $3 \%$ of patients with closed trauma and $2 \%$ to $9 \%$ of those who suffered penetrating cervical and/ or thoracic injuries ${ }^{3,4}$. In our series of nine patients with tracheobronchial lesions, two were due to closed trauma.

There are other causes of injury: foreign body aspiration, inhalation wounds and even iatrogenic injuries, such as intubation lesions, but they are uncommon.

Cervical tracheal lesions are generally produced by penetrating wounds, being rare in the closed trauma, which preferentially causes lesions in the intrathoracic trachea and stem bronchus, $80 \%$ of which up to $2.5 \mathrm{~cm}$ from the carina. Although most studies show a higher incidence of lesions in the right stem bronchus, considered less protected by the mediastinal structures, in our series the two patients with closed trauma had lesions in the left bronchus. There was a cervical tracheal injury with a stabbing wound and another with a gunshot wound ${ }^{3,5,9-13}$.

The clinical picture varies according to lesion location and severity, and may not be immediately expressed, such as in closed trauma where it is believed to occur in up to two thirds of the tracheobronchial lesions, especially when on the left. In one of our cases, the diagnosis was made after three days and the lesion was on the left.

Subcutaneous and mediastinal emphysema were the most common signs. We did not observe hemoptysis, and pneumothorax occurred in all patients with intrathoracic airway lesions. These are non-specific signs, such as dyspnea, but should be particularly valued when they persist even after initial treatment such as chest drainage.

The radiological findings suggestive of tracheobronchial lesions are pneumothorax, pneumomediastinum, subcutaneous emphysema with air in the deep cervical fascias and a specific but not very sensitive signal is the "fallen lung", generally seen in cases of complete bronchial transection. The literature highlights the presence of pneumothorax in $70 \%$ and pneumomediastinum in up to $60 \%$ of the cases. The presence of fractures of the first three ribs and sternumclavicular disjunction should also prompt suspicion ${ }^{3,4,9,11,12}$.
It is important to highlight that up to $10 \%$ of patients with tracheobronchial lesions may present normal radiological examination in the immediate post-trauma period ${ }^{6,14}$.

Radiological changes are non-diagnostic, but the presence of pneumomediastinum, persistent refractory pneumothorax, atelectasis and subcutaneous emphysema should raise the clinical suspicion of airway injury, and in this case, bronchoscopy should be the examination of choice, which should locate and characterize the lesion ${ }^{4}$. The presence of blood in the airways or difficulty in visualizing the distal bronchial tree may compromise the exam power of resolution. Therefore, some authors recommend repeating the bronchoscopy in the face of clinical suspicion. In intubated patients, where possible, the tube should be removed for proper evaluation $4,6,11,15$.

Regarding bronchography, it is believed to have value for chronic lesions, but it is not a recommended test for the diagnosis of injuries soon after trauma, being even contraindicated in this phase by some authors ${ }^{9}$. We had a single case where it was performed, suggesting a bronchial injury that was confirmed intraoperatively, but it is not our exam of choice. It is worth noting that the diagnosis is not recognized in $79 \%$ of patients, since the peribronchial tissues maintain the airway flow temporarily satisfactory ${ }^{10}$.

The ability of computed tomography to make this diagnosis has been improving lately, having been decisive in one of our patients, in whom bronchoscopy did not show the bronchial lesion ${ }^{16-19}$. Recently, with the advent of multi-channel tomography, the method's resolution power in the diagnosis of tracheobronchial lesions has been highlighted ${ }^{20-24}$.

As for associated lesions, the esophagus is the most exposed organ in cervical tracheal trauma, reason why it should always be investigated ${ }^{2,4}$. In our series, of the two cervical tracheal wounds, one had an esophageal lesion that was debrided and sutured. In closed trauma, the incidence of esophageal injury is very low (less than $1 \%$ ), but this diagnosis should not be forgotten. Due to the same mechanism of trauma, other lesions should be investigated, such as pulmonary contusion associated with multiple rib fractures, scapular fracture and vascular lesions $4,5,12$. We had one patient with scapular-humeral disjunction and brachial plexus lesion, with concomitant subclavian injury, and another with severe pulmonary 
contusion associated with multiple rib and scapula fractures, with important left shoulder deformity.

Of the thoracic penetrating injuries, only one had arterial lesion associated with the bronchial injury and this patient underwent inferior lobectomy due to intraoperative hemodynamic instability.

Regarding the approach to tracheobronchial lesions, it is believed that the majority can be treated by debridement and primary repair, both in penetrating and closed trauma4,6,11,14. In some situations, end-toend anastomosis may be necessary in both cervical and intrathoracic lesions, and tracheostomy is not mandatory. Small airways lacerations can be treated non-operatively, in selected, hemodynamically stable patients without associated lesions ${ }^{4,9,14}$.

The lesions repair was done with nonabsorbable monofilament suture or with Polyglactin (Vicryl) in separate stitches. A muscle flap was used between the trachea and the esophagus in the combined lesion in one of our cases, as some authors suggest, to avoid late tracheoesophageal fistulas ${ }^{13,19}$.

The access of choice for the intrathoracic lesions is the right thoracotomy, which allows to approach the majority of the intrathoracic lesions, avoiding the aortic arch and better exposing the airway, leaving the left thoracotomy, and even the sternotomy, for more distal left lesions or more complex ones ${ }^{7,11}$.

Pulmonary resections are an alternative, especially in cases of vascular lesions associated with hemorrhage, which makes the bronchial repair difficult. We had two cases in which this was the option: one right inferior lobectomy with vascular lesion and one left pneumonectomy due to complete lesion in the emergence of the stem bronchus, though without vascular injury.

The excellence of anesthesia is fundamental for the success of the procedure, both in terms of adequate positioning of the endotracheal tube and in the control of airways pressure ${ }^{5,9}$. In our series, we achieved selective intubation in only three cases and this certainly facilitated the approach to the lesion. In the postoperative period, the correct positioning of the tube is also essential, preserving the suture line and reducing pressure on it.

In special situations, particularly in complex and extensive lesions, the use of stents to avoid stenosis has been discussed and can be maintained for six to 18 months $^{5,6}$. We have no experience with the use of airway prostheses in trauma in our Service, and it is our conduct to operate the patient as soon as possible.

The overall estimated mortality for tracheobronchial lesions is $30 \%$. We did not have deaths in our series, but our casuistry is very small. The authors consulted suggest that early diagnosis and treatment of tracheobronchial lesions are associated with better results, with a greater possibility of primary repair, preserving as much as possible the functioning pulmonary parenchyma, and minimizing the risks of stenosis, empyema and other complications, more common in late repairs. We had two patients who evolved with pleural empyema, one with associated lesion of the intrathoracic esophagus and the other operated after thirty days of injury. The other patients had a good evolution.

We believe that the mechanism of trauma and clinical findings should be valued in the suspicion of airway injury and justify the insistence on early diagnosis.

\section{R E S U M O}

Objetivo: discutir os aspectos clínicos e terapêuticos de lesões traqueobrônquicas em vítimas de trauma torácico. Métodos: análise de dados dos prontuários de pacientes com lesões traqueobrônquicas atendidas na Santa Casa de São Paulo no período de abril de 1991 a junho de 2008. A caracterização da gravidade dos doentes foi feita por meio de índices de trauma fisiológico (RTS) e anatômicos (ISS, PTTI). O TRISS (Trauma Revised Injury Severity Score) foi utilizado para avaliar a probabilidade de sobrevida. Resultados: nove doentes tinham lesões traqueobrônquicas, todos do sexo masculino, com idades entre 17 e 38 anos. Os valores médios dos índices de trauma foram: RTS- 6,8; ISS- 38; PTTI-20,0; TRISS-0,78. Com relação ao quadro clínico, seis apresentaram apenas enfisema de parede torácica ou do mediastino e três doentes se apresentaram com instabilidade hemodinâmica ou respiratória. O intervalo de tempo necessário para se firmar o diagnóstico, desde a admissão do doente, variou de uma hora a três dias. Cervicotomia foi realizada em dois pacientes e toracotomia foi realizada em sete $(77,7 \%)$, sendo bilateral em um caso. O tempo de internação variou de nove a 60 dias, média de 21 dias. Complicações apareceram em quatro pacientes (44\%) e a mortalidade foi nula. Conclusão: o trauma da árvore traqueobrônquica é raro, pode evoluir com poucos sintomas, o que dificulta o diagnóstico imediato, e apresenta alto índice de complicações embora com baixa mortalidade.

Descritores: Brônquios. Traumatismos Torácicos. Cirurgia Torácica. Traqueia. 


\section{REFERENCES}

1. Marsico GA. Lesões da traqueia e grandes brônquios. In: Marsico GA. Trauma torácico. 1a ed. Rio de Janeiro: Revinter; 2006. p.147-58.

2. Bertelsen S, Howitz P. Injuries of the trachea and bronchi. Thorax. 1972;27(2):188-94.

3. Deslauriers J, Beaulieu M, Archambault G, LaForge J, Bernier R. Diagnosis and long-term follow-up of major bronchial disruptions due to nonpenetrating trauma. Ann Thorac Surg. 1982;33(1):32-9.

4. Amauchi W, Birolini D, Branco PD, Oliveira MR. Injuries to the tracheobronchial tree in closed trauma. Thorax. 1983;38(12):923-8.

5. Taskinen SO, Salo JA, Halttunen PE, Sovijärvi AR. Tracheobronchial rupture due to blunt chest trauma: a follow-up study. Ann Thorac Surg. 1989;48(6):846-9.

6. Kiser AC, O`Brien SM, Detterbeck FC. Blunt tracheobronchial injuries: treatment and outcomes. Ann Thorac Surg. 2001;71(6):2059-65.

7. Champion HR, Saco WJ, Copes WS, Gann DS, Gennarelli TA, Flanagan ME. A revision of the Trauma Score. J Trauma. 1989;29(5):623-9.

8. Baker SP, O'Neill B, Haddon W Jr, Long WB. The injury severity score: a method for describing patients with multiple injuries and evaluating emergency care. J Trauma. 1974;14(3):187-96.

9. Soothill EF. Closed traumatic rupture of the cervical trachea. Thorax.1960;15(1):89-92.

10. Angood PB, Attia EL, Brown RA, Mulder DS. Extrinsic civilian trauma to the larynx and cervical trachea--important predictors of long-term morbidity. J Trauma. 1986;26(10):869-73.

11. Roxburgh JC. Rupture of the tracheobronchial tree. Thorax. 1987;42(9):681-8.

12. Mussi A, Ambrogi MC, Ribechini A, Lucchi M, Menoni F, Angeletti CA. Acute major airway injuries: clinical features and management. Eur J Cardiothorac Surg. 2001;20(1):46-51; discussion 51-2.

13. Cassada DC, Munyikwa MP, Moniz MP, Dieter RA Jr, Schuchmann GF, Enderson BL. Acute injuries of the trachea and major bronchi: importance of early diagnosis. Ann Thorac Surg. 2000;69(5):1563-7.

14. Edwards WH Jr, Morris JA Jr, DeLozier JB $3^{\text {rd }}$, Adkins RB Jr. Airway injuries. The first priority in trauma. Am Surg. 1987;53(4):192-7.

15. Kirsh MM, Orringer MB, Behrendt DM, Sloan H. Management of tracheobronchial disruption secondary to nonpenetrating trauma. Ann Thorac Surg. 1976;22(1):93-101.

16. Chen JD, Shanmuganathan K, Mirvis SE, Kileen $\mathrm{KL}$, Dutton $\mathrm{RP}$. Using $\mathrm{CT}$ to diagnose tracheal rupture. AJR Am J Roentgenol. 2001;176(5):1273-80.

17. Noboru N, Fumio M, Shunsuke $Y$, Kichizo K, Masayuki Y, Sadaki, et al. Chest radiography assessment of tracheobronchial disruption associated with blunt chest trauma. J Trauma. 2002;53(2):372-7.

18. Balci $A E$, Eren $N$, Eren $S$, Ulkü R. Surgical treatment of post-traumatic tracheobronchial injuries: 14-year experience. Eur J Cardiothorac Surg. 2002;22(6):984-9.

19. Helmy N, Platz A, Stocker R, Trentz O. Bronchus rupture in multiply injured patients with blunt chest trauma. Eur J Trauma. 2002;28(1):31-4.

20. Le Guen M, Beigelman C, Bouhemad B, Wenjïe $Y$, Marmion F, Rouby JJ. Chest computed tomography with multiplanar reformatted images for diagnosing traumatic bronchial rupture: a case report. Crit Care. 2007;11(5):R94.

21. Faure A, Floccard B, Pilleul F, Faure F, Badinand B, Mennesson $\mathrm{N}$, et al. Multiplanar reconstruction: a new method for diagnosis of tracheobronchial rupture? Intensive Care Med. 2007;33(12):21738. Epub 2007 Aug 8.

22. Kaewlai R, Avery LL, Asrani AV, Novelline RA. Multidetector CT of blunt thoracic trauma. Radiographics. 2008;28(6):1555-70.

23. Savas $R$, Alper $H$. Fallen lung sign: radiographic findings. Diagn Interv Radiol. 2008;14(3):120-1.

24. Tamura M, Oda M, Matsumoto I, Fujimori H, Shimizu Y, Watanabe G. Double-barrel reconstruction for complex bronchial disruption due to blunt thoracic trauma. Ann Thorac Surg. 2009;88(6):2008-10. 
Received in: 19/07/2016

Accepted for publication: 01/10/2016

Conflict of interest: none.

Source of funding: none.

\section{Mailing address:}

Roberto Gonçalves

E-mail: rgtorax@yahoo.com.br 